\title{
Placing Information Skills in Context: As a Tool in Developing Teachers' Writing Competency and Promoting Deeper Learning
}

\author{
Faziah Abdul Karim ${ }^{1 *}$ \\ ${ }^{1}$ Training Development Department, \\ Institute of Teacher Education Tun Hussein Onn Kampus, Batu Pahat, Johor, MALAYSIA \\ *Corresponding Author
}

DOI: https://doi.org/10.30880/jstard.2020.02.03.006

Received 30 September 2020; Accepted 30 November 2020; Available online 31 December 2020

\begin{abstract}
In recent years, library media experts have endeavored to move from teaching isolated library skills to teaching integrated information skills. Information skills are integrated effectively when the skills directly relate to the content area curriculum and classroom assignments and are incorporated in a logical and systematic information process model. This study examines the level of teachers' ability to apply information skills in Reports Writing of teachers attending the English Language Professional Development (CPD) Course. Although random sampling would ensure validity and reliability, there is no true sampling as the course participants are the only subjects here. The whole group of 24-course participants is involved in this study and is used as a sample of the study. A Likert scale set with a four-point Likert scale is used in assessing this study. The reliability value of questionnaire items in the pilot study was Cronbach alpha $=0.90$. The results of this study were analyzed using Statistical Packages for Social Science (SPSS) version 22.0 using simple percentages and to obtain mean analysis, standard deviation, and correlation. $($ Mean $=3.12, \mathrm{SD}=.52)$ locating information source, $($ Mean $=3.1, \mathrm{SD}=.496)$ extracting relevant information, (Mean $=3.04, \mathrm{SD}=.53$ ) synthesizing the information and evaluating to communicate the information (Mean $=3.07$, $\mathrm{SD}=.52$ ). The findings also show the correlation of locating information source with extracting relevant information $(r=.975)$, synthesizing the information $(r=.976)$, and evaluating to communicate the information $(\mathrm{r}=.984)$ is at a high level. To ensure that the principles of triangulation eliminate personal assumptions entering the findings, various instruments were also used. A pre-test and a post-test were given to assess respondents' entry knowledge before the start of the course and their overall performance at the end of the course. The best result in the pre-test was in the 'summary' and the best score for the post-test was in 'Direct Quotations'. Assessing the respondents' reports writing was done to ascertain the effective and accurate application of information skills in their report writings. More than fifty percent of the course participants obtained a high score for their report writing marks. They had manifested a good mastery of information skills and in terms of precision of ideas and thoughts as well as coherence and cohesion in writing, the course participants have developed their competency highly and the process of deeper learning, in a recursive, mutually reinforcing cycle. The results of this study would be of considerable significance to lecturers or trainers in the teaching of report writing and preparing course participants to write with higher competency.
\end{abstract}

Keywords: Information skills, writing competency, deeper learning, continuing professional development (CPD)

\section{Introduction}

The need for English proficiency has become increasingly crucial. In response to calls by the Ministry of Education to improve English language proficiency among teachers, numerous Continuing Professional Development (CPD) Courses for all primary school English language teachers have been conducted .The English Language Teaching 
Centre (ELTC) together with Institute of Teacher Education Malaysia has conducted CPD such as the Highly Immersive Programme (HIP), the Professional Upskilling of English Language Teachers (Pro-ELT), the English Language Enhancement in Schools Programme (PPKBIS) and the Dual Language Programme (DLP). Institute of Teacher Education also works in close relationships with schools and the Ministry of Education in supporting teachers' CPD. Additionally, lecturers in Institute of Teacher Education render their professional assistance to the Ministry of Education. They are judiciously positioned to evaluate the quality of professional development, monitor its effectiveness in the classroom, and recommend the directions that CPD might proceed in the future. All these initiatives are to focus on the improvement of the teachers' proficiency and also competency. In a teaching-learning situation where the motivation to learn the English language is lacking, it is clear that the impetus must come from the teacher himself. Level of English proficiency among teachers should be at a mastery level because they need their language ability to teach the target language effectively and competent in order to provide optimal learning opportunities in the language classroom. It gives a strong presumption that teachers' general proficiency significantly affects the way they use language in the classroom to promote learning. Therefore, the demands on English language teachers and how they are trained are increased and a major force of these efforts have focused on improving teachers' English language proficiency.

A widely cited definition of CPD is offered by Day: '....all natural learning experiences and those conscious and planned activities which are intended to be of direct or indirect benefit to the individual, group or school and which contribute through these to the quality of education in the classroom. It is the process by which, alone and with others, teachers ... acquire and develop critically the knowledge, skills and emotional intelligence essential to good professional thinking, planning and practice.' (Day, 1999: 4). Consequently, it is essential for teachers to attend CPD as it ensures them continue to be competent in their profession and ensures their capabilities keep pace with the current standards of others in the same field. Research has shown that, in a responsive social setting, learners can adopt the criteria for competence they see in others and then use this information to judge and perfect the adequacy of their own performance (National Research Council, 2001). There are more reasons why teachers need to continue their learning once they are qualified. Firstly, they can be vigilant in observing what is and isn't succeeding thus they are doing the process of reflection, teachers may find it helpful to 'observe' themselves. Secondly, the teachers need to discover the other ways there are of doing things and there are better ways of finding out new ideas, techniques, and approaches. Earley and Porritt, (2014) have argued that improving student outcomes is the primary purpose of CPD and that students' needs (rather than teachers') should be the starting point in decisions about the kinds of CPD that are pursued. For a more detailed discussion, Borg, (2015) suggests that CPD can achieve positive and sustained impacts on teachers, learners, and organizations when student learning provides the motivation for professional learning. Thus, teachers' professional development should be understood as a lifelong learning process, rather than a one-off event.

\section{The Big6 Model}

The Big6 information problem-solving approach is an information literacy model developed by Mike Eisenberg and Bob Berkowitz of USA in 2001. It is an information search process model which states how people of all ages solve an information problem. It integrates information search and use skills along with technology tools in a systematic process to find, use, apply, and evaluate information for specific needs and tasks. The Big6 Skills are best learned when integrated with classroom curriculum and activities. It is most widely known and widely used model to teach information and technology skills in the world. According to this model the successful information solving process encompasses six or six steps with two sub-stages or sub- steps shown below.

\section{Big6 Inquiry Process}

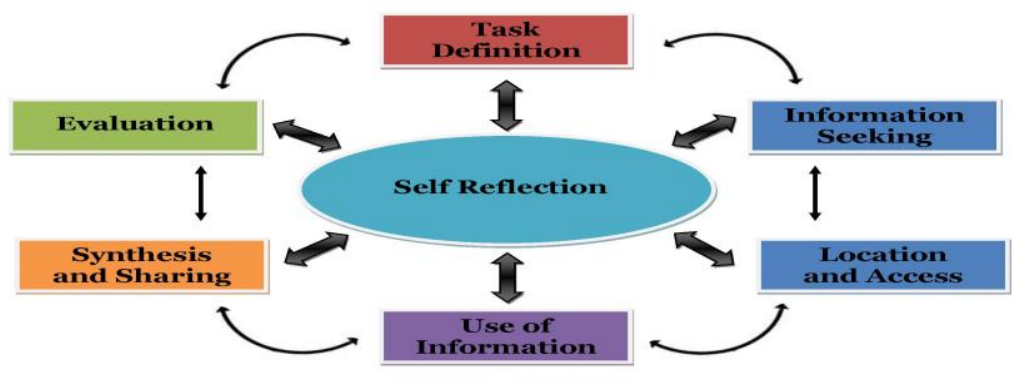

Fig. 1 - Big 6 inquiry process 


\section{Locate Information Source}

Locating information source is the third stage. It involves finding out where the information can be accessed. In the local library, browsing the shelves, finding a library's online catalogue, or making use of search engines, meta search tools, and subject trees are ways to locate information. Finding information within the sources, understanding keywords and guide words, searching engines and databases will help locate useful information.।

\section{Extract Relevant Information}

Extracting relevant information is the fourth stage. Concept mapping software and graphic organizers are useful during this stage to keep track of notes. There are several ways that notes can be made and graphic organizers can be used. Not all notes have to be written. Images have been used to express thoughts in note-making. (Burke, 2008).

\section{Synthesize the Information}

Synthesizing is the fifth stage. This is the stage where information extracted is determined useful or is not. The information that remains will be part of a speech, report, or presentation of some kind and is presented to an audience in a creative way. Also, the research findings can be translated into a new and appealing format that is pleasing to the senses by using charts, graphs, pictures, sound, 3D objects, and animation. Whereby, a speech is delivered with a multimedia presentation. Mike Frerichs, a school media specialist, says that, the concept of design is built into the Big6 research process, and that it is, especially effective to teach design as part of the Big6 number five synthesis stage. (Frerichs, 2008).

\section{Evaluation to Communicate the Information}

Evaluation is the sixth and final stage. Now, it is time to judge findings that have been presented to others. Judging the effectiveness of the product requires thinking about how well the presentation was received. Next, judging the efficiency of the process by reviewing what has been accomplished in each of the stages. This is effectively where the Big6 starts over.

This study is to examine teachers' ability to apply information skills for academic purposes among the English Language Proficiency CPD course participants. Information Skills here refer to; locate information source, extract relevant information, synthesize the information and evaluation to communicate the information (transferable) The study also sets out to investigate what course participants' attitude in applying Information skills. It further examines the content of course participants' report and how useful information skills had been for writing out their reports.

The specific objectives of this study are to: (a) identify the level of teachers' ability to apply information skills used in the Report writing, (b) show the correlation of locating information source, extracting relevant information; synthesizing the information and evaluating to communicate the information (transferable), (c) investigate teachers' writing competency and whether the teachers' writing competency have improved, and (d) investigate what teachers' attitude in applying Information skills.

\section{Literature Review}

The theoretical foundations of this study are fundamentally on information skills that part of the information phenomenon, teacher competency in writing, and how deeper learning is encouraged. This study was inspired by the Big6 Process. Michael Eisenberg and Bob Berkowitz introduced the Big6 in 1988. (Eisenberg and Berkowitz 1990). The Big6 is a six-stage model to help anyone solve problems or make decisions by using information. It is an effective tool for helping students learn the research process which allows researchers to effectively find, use, apply, and evaluate information. Eisenberg and Berkowitz (1990, 1999, 2000) emphasize one essential guideline for implementing information skills instruction-integration with the classroom curriculum. From experience and research, we know that teaching information skills is most effective when combined with subject area units, lessons, and assignments. One of the inspirational readings on a case study conducted by Sara Wolf (2003),

on the Big Six Information Skills as a Metacognitive Scaffold examined the effect of Big6 on grade 8 students who were asked to write about the events surrounding the African-American Civil Right Movement. As Eisenberg (1998) emphasized in her study that Big6 is an inquiry process which is very critical to students' learning in all areas like social studies (research process), science (experimental process), mathematics (problem solving process) this study was found equally helpful in the development of cognitive learning as it provides a strategy for developing the foundations of higher order thinking skills, reasoning, and critical thinking. Information literacy skills as pointed out by Kovalik, Jesen, Schloman and Tipton (2010) refers to an individual's ability to recognize when there is a need for information, and to be able to identify, locate, evaluate, and effectively use that information for the issue or problem at hand.

The Big6 is used to teach inquiry, information and technology skills in thousands of K-12 schools, higher education institutions, and corporate training programs. The Big6 information problem-solving process is applicable whenever 
people need and use information that integrates information search and use skills along with technology tools in a systematic process to find, use, apply, and evaluate information for specific needs and tasks.

After gaining its popularity since the mid-1980s, in January of 2018, A new non-profit organization, The Big6.org, has been established to carry the mission forward (website thebig6.org.). The Big6.org was launched with the mission of The Big6.org is to use the Big6 model, approach, and programs to promote essential, lifelong information problemsolving skills thinking, learning, and teaching in schools and informal learning contexts. Recently, Colet Bartow and John Marino, the New Big6.org team members, broadcasted team talk with Mike Eisenberg to discuss the origin stories with the Big 6 information problem solving process, the Big 6 information problem solving model and how the Big 6 is moving into the future. (Originally broadcast January 21, 2019 on Facebook Live). The most recent article written about Big6 by Colet Bartow (August 25, 2019), "The Big 6 and Super 3 provide access points and clarity to the fundamental building blocks of learning for any age student, teacher, teacher-librarian, school leader, trustee-really anyone! It really is time to make the idea stick that PK-Lifetime Learning is really about empowering and enabling all learners to identify, solve, present, create, and improve upon information problem solving in all aspects of life". Bartow's comments were influenced by an article titled 6 Rules to Break for Better, Deeper-Learning Outcomes written by Monica Martinez (November 13, 2014), she states, "Incorporate deeper learning as you empower students to seek knowledge from many sources, use tools relevant to their lives, and embrace the lessons of failure".

In reviewing previous works on 'Deeper learning", Monica Martinez, author of Deeper Learning: How Eight Innovative Public Schools Are Transforming Education in the Twenty-First Century, shares strategies that offer a motivating and extended vision of what's conceivable in schools today. In her article, she recommends a framework for teachers and schools to adapt to the situation of preparing all students for college, careers, and the present reality. Martinez identifies six strategies and pedagogical practices for deeper learning outcomes; empower students as learners, contextualize knowledge, connect learning to real-world experience, extend learning beyond the school, customize learning experience, and incorporate technology.

According to the Hewlett Foundation definition (William and Flora Hewlett Foundation, 2013; Chow, 2010), deeper learning is the term that refers to the competencies, knowledge, and skills that students must develop to succeed in the $21^{\text {st }}$ century, and therefore what they should know and be able to do when they graduate from our public education system. Deeper learning competencies address three domains: cognitive, interpersonal, and intrapersonal (Pellegrino, Hilton, Herman, et al., 2012). Cognitively, students master the content knowledge, they are more able to transfer knowledge to other situations or tasks. That is, they develop the ability to synthesize and analyse information; frame questions; and recognize patterns, trends, and relationships so they can identify and solve problems as well as assess or evaluate the eff ectiveness of the proposed solution. Taken together, the deeper learning competencies result in students' ability to use and apply what they have learned. This ability, known as knowledge transfer, is widely recognized as critical to succeeding at novel tasks or new contexts (Pellegrino, Hilton, Herman, et.al., 2012). Strategies that facilitate deeper learning for students will help prepare students to deal with the changes and fulfill the demand for higher-level skills and provide them with an ability to learn in the globally connected economy. A recent report by workforce economist emphasised the increasing need for individuals who can work across networks of people, with greater efficiency and at an accelerated pace (Carnevale and Rose, 2015:12).

Through deeper learning which often involves shared learning and interactions with others in a community, the individual develops expertise in a particular domain of knowledge and/ or performance. It is also referred to the blend of both knowledge and skills. While other types of learning may allow an individual to recall facts, concepts, or procedures, deeper learning allows the individual to transfer what was learned to solve new problems. It is stated in CCSSI (2012), the English language arts standards call on students to synthesize and apply evidence to create and effectively communicate an argument and are likely to shape any attempt to infuse deeper learning initiatives into are likely to shape any attempt to infuse deeper learning initiatives into school curricula also in teachers' training curricula.

Essentially, the proposed adoption of Common European Framework of Reference (CEFR) for Languages in the development of the English education system in Malaysia is to meet the international standard (Ministry of Education Malaysia Blueprint, 2015 (b): 62). CEFR is an international standard for describing language ability based on a sixpoint scale, from A1 for beginners, up to $\mathrm{C} 2$ for those who have mastered a language. Professor John Trim, one of the CEFR authors described 'What we were aiming at was something which will be a common reference point that people working in different fields and people using it for entirely different things and in very different ways could refer to in order to feel that they were part of a common universe' (Saville 2005:281). Recent documents and plans released by Malaysian government, such as the English Language Roadmap 2015-2025 which are part of the Malaysian Education plan have clearly indicated that the Malaysian government is expediting the implementation of the framework into the current education system. (Nurul farehah \& Mohd Sallehhudin Aziz (2017). In the context of English language proficiency, the Ministry of Education expects Malaysian students to attain the target proficiency level expressed in terms of the CEFR set for each stage of education (English Language Education Reforms in Malaysia: The Roadmap 2015-2025, 2016, pp. 5-6). Inevitably, by the year 2016, all English language teachers must achieve a minimum level of $\mathrm{C}$, which is equivalent to a capable/expert user of the English language according to the CEFR to enable them to continue to teach the subject. According to Education Ministry deputy director-general Dr. Habibah Abdul Rahim, "Teachers need to be proficient in the English language in order to facilitate teaching and learning, as well as help 
students acquire targeted CEFR levels. It is only English language option teachers who have to take MUET and achieve at least the C1 level. It is not compulsory for non-English language option teachers." (thestar.com.my 2019).

Writing competencies belong to two broad groups: writing proficiency and writing task-related skills. The former includes abilities such as punctuation, grammar, word choice and composition, and latter-related skills include an ability to source information and apply suitable writing conventions (Pajares, 2003). Thus, it can be acclaimed that the language teacher competencies in the classroom consists of teachers use language both as a medium for and object of instruction. They require language skills that include knowledge of the structures and functions of language, as well as fluency in speaking, writing, listening, and reading, and the ability to teach these same skills to their students. Mastering in English means knowing how to communicate in English. This involves the productive skills and the receptive skills. Linguistic competence is a term that associate with Chomsky (2000), who made the distinction between people's knowledge of language (competence), and that knowledge put to use in real situations (performance). In as much as Intellectual abilities is one of competences of professional development in teacher training. It is Intellectual abilities which is the most relevant because this is where the writing competence is presented as one the priorities to be developed in teachers. As writing is an essential competence, in teacher training, writing is an individual pedagogical action that aids teachers to interpret the school and community context in order to set new objectives and participate to rebuild and transform education. The SEP (2002) establishes in its official educational documents that the writing competence is an important skill that has to be included in the programs which are schools that specialize in training teachers. It is important that teachers possess competences, knowledge and skills, and be able to integrate the teaching program curricula with the use of ICT (Information and Communications Technology) and Information Skills. This is in line with the UNESCO Competency Framework for Teachers. The ICT CFT consists of 18 competencies organized according to the six aspects of teachers' professional practice, over three levels of teachers' pedagogical use of ICT. The underlying idea is that teachers who have competencies to use ICT in their professional practice will deliver quality education and ultimately be able to effectively guide the development of students' ICT (UNESCO. 2015).

Whereas, Information skills are techniques which teachers learnt during their time at university to help them not only whilst they are studying, but throughout their lives, at any time when they may need to find and use information. Teachers have developed some information skills already without even realizing it for example looking for information on the Internet is an "information skill". When learners/ teachers read, write or think at a high level, compare ideas and do/prepare assignments, all the skills they apply in these situations have to do with using information in some ways. Information skills are an important part of becoming information literate which are abilities to use information effectively vary considerably. It is interesting to note that The Partnership for $21^{\text {st }}$ Century Skills had published its Framework for $21^{\text {st }}$ Century Learning (2004), which includes eleven core subjects, four interdisciplinary themes, and three sets of skills that support students' learning across all these subjects and themes including a set titled Information, Media and Technology Skills. In addition to that, the International Society for Technology in Education (ISTE, 2017) added research and information fluency as a major category in its revised Standards for Students. Likewise, American Association of School Librarians (AASL, 2018) threaded information literacy throughout its Standards for the $21^{\text {st }}$ Century Learner. At present, the American Common Core State Standards for English Language Arts \& Literacy in History/Social Studies, Science, and Technical Subjects, not only focus on reading informational text but note the need for students to be able to gather, comprehend, evaluate, synthesize, and report on information and ideas and to produce and create a high volume and extensive range of print and nonprint text in media forms old and new (CCSSI 2012).

\section{Methodology}

\section{Design}

This study is a quantitative study that aims to identify the level and the relationship between four variables. In this study, a measuring tool was used to elicit data through the Monash University Library Questionnaire on Information Literacy which the questionnaire was modified according to the suitability of the respondents. The data collected were analysed using Statistical Packages for Social Science (SPSS) version 22.0 to obtain percentages, mean analysis, standard deviation, and correlation. In order to ensure validity and reliability, a pilot study was conducted using 20 respondents. The reliability test of Cronbach Alpha showed a high value of 0.90 for the entire 44 items of the questionnaire. Validity test using Kaiser Meyer Olkin (KMO) and Bartlett's shows the validity value obtained is also 0.93 for 44 items answered by the respondents. This questionnaire was divided into two parts: A and B. Part A contains questions related to student demographics. Part B contains questions to evaluate the components of information skill used in the Report Writing; locating information source, extracting relevant information, synthesizing the information and evaluating to communicate the information. 
Table 1 - The total number of questionnaires surveyed

\begin{tabular}{lll}
\hline Field & Number of Question & Question Number \\
\hline locating information source & 12 & $1-12$ \\
\hline extracting relevant information & 9 & $13-21$ \\
\hline synthesizing the information & 13 & $22-34$ \\
\hline evaluating to communicate the information & 10 & $35-44$ \\
\hline
\end{tabular}

To determine the mean value, the mean score of the Sugiyono (2001) table in Table 2 is used to evaluate the mean levels in the four components of the information skill studied.

Table 2 - Mean Scale Score

\begin{tabular}{ll}
\hline Rating (Mean) & Evaluation Criteria \\
\hline $1.00-1.75$ & Very low \\
\hline $1.75-2.50$ & Low \\
\hline $2.50-3.25$ & High \\
\hline $3.25-4.00$ & Very high \\
\hline
\end{tabular}

Source: Sugiyono, 2001

\section{Sampling}

The selection of CPD course participants and the sample was based on purposive sampling. In determining the respondents' sample, the researcher chose all 24 teachers who had attended CPD course of In-Service English Language Proficiency. All 24 teachers had been involved in pilot studies and in the actual study. Most of the teachers in this study were trained in TESL Methodology. A few did not have a TESL background. They were Bahasa Malaysia, Chinese or Tamil language teachers. There were 19 females and 5 males in this study.

\section{Instruments}

\section{A pre-test and post-test}

The pre-test was administered before the start of the course to assess respondents' prior knowledge of Note taking using Information Skills. The test required the respondents to quote directly from the passage, paraphrase at least one paragraph, summarise the whole passage and evaluate the passage on the whole. They were given one hour to accomplish the task. At the end of the research, the same test was administered as the post-test purely to gauge the comprehension and application of information skills for academic purposes. The allocation of marks for the test was as follows:

Locate and Access of information within sources (Direct Quotation)

Extract and use of relevant information (Paraphrase)

Synthesis and organise information from multiple sources (Summary) -

Evaluate the result effectiveness and the process efficiently (Evaluation)

$$
\begin{array}{lr}
- & 10 \text { marks } \\
- & 20 \text { marks } \\
10 & \text { marks } \\
- & 10 \text { marks }
\end{array}
$$

\section{Report Writing}

A close study of the respondents' reports writing was made to ascertain the application of the information skills.

\begin{tabular}{|c|c|c|c|}
\hline $\begin{array}{l}\text { Content } \\
\text { Language } \\
\text { Organisation and Presentation of text } \\
\text { Growth and Development }\end{array}$ & $\begin{array}{l}- \\
- \\
-\end{array}$ & $\begin{array}{l}10 \text { marks } \\
5 \text { marks } \\
20 \text { marks } \\
5 \text { marks }\end{array}$ & \\
\hline Total & & 40 & marks \\
\hline
\end{tabular}
The relevancy of the content and the accuracy as well as the appropriateness of language used was also noted in order to get an insight into the writing proficiency of respondents.

The reports writing was assessed based on the following criteria: 


\section{Journals}

A journal was a written account of participants' involvement in the classroom- based activity and their progress in the report writings. It gave an insight into how is done as regards to their report on their training activity. In the journals, the participants reflected that the input received on information skills, followed by practical sessions to practise skills to dove-tail into search for information regarding their report writing topic had helped them tremendously at the initial stages.

Respondents were also advised to keep journals where they reflected upon the course component on information skills and expressed their feelings of what they liked or disliked about the course component and how useful information skills had been for writing out their reports.

\section{Triangulation}

Various instruments were used in this study purely to achieve greater triangulation and credibility of results. To ensure that the principles of triangulation eliminate personal prejudices entering the finding, instrumentation comes also in the form of: (a) Introspection to find out the attitudes towards writing and (b) Informal interviews to find out what input has been most effective in helping them in their writing of reports.

\section{Findings and Discussion}

\section{Demographic Profile of Respondents}

Among the 24 respondents, $20.8 \%$ were males while $79.2 \%$ were females. The females outnumbered the males. The ages range from 23 to 43 (34\%), from 31 to $35(40 \%)$ and over 35 is (26\%). The ethnic group of the respondents showed that the majority of the respondents were Malays (62.5\%), Chinese (20.8\%), and Indian is (16.7\%). The respondents were specialized in different majors, including teachers who specialized in TESL (60\%), Bahasa Melayu $(10 \%)$, the Chinese language $(18 \%)$, and the Tamil language is $(12 \%)$. The years of teaching experience too, varied from a minimum of $3 \frac{1}{2}$ years to a maximum of 23 years. All of them had access to computer at home and $96.6 \%$ had good internet connection. They reported their weekly computer usage as 0-2 hours (10\%), 3-5 hours (21\%), 6-10 hours (31\%) and over 10 hours is $(38 \%)$. About $68.4 \%$ of the course participants were from rural schools.

\section{Evaluation on Level of Teachers' Ability to Apply Information Skills Used in the Report Writing}

The level of teachers' ability to apply information skills used in the report writing: locating information source, extracting relevant information, synthesizing the information, and evaluating to communicate the information.

Table 3 - Mean score for LOC, EXTRACT, SYNTHESIZE AND EVALUATE

\begin{tabular}{lllll}
\hline No. & Skills & Mean & $\begin{array}{l}\text { Standard } \\
\text { Deviation }\end{array}$ & Level \\
\hline 1 & locating information source & 3.12 & .52 & High \\
\hline 2 & extracting relevant information & 3.10 & .50 & High \\
\hline 3 & synthesizing the information & 3.04 & .53 & High \\
\hline 4 & evaluating to communicate the information & 3.07 & .52 & High \\
\hline
\end{tabular}

Indicator:

LOC- locating information source

EXTRACT- extracting relevant information

SYNTHESIZE - synthesizing the information

EVALUATE - evaluating to communicate the information

In Table 3, data analysis finds that all skill levels are in place at a high level of locating information source (mean $=3.12$, s.d. $=.52)$, extracting relevant information $($ mean $=3.1$, s.d. $=.50)$, synthesizing the information $($ mean $=3.04$, $\mathrm{s} . \mathrm{d}=.53)$ and evaluating to communicate the information $($ mean $=3.07$, s.d. $=.52)$ among the teachers.

In Table 4, the mean score for each item is at a high level with the overall achievement of the mean level of 3.0 . There is a questionnaire that achieves a very high level of item 5 (mean $=3.3$ ) which shows that teachers had constructed and used effective search strategies and techniques for the information retrieval system or tool selected. 
Table 4 - Mean Score for Locating Information Source Item

\begin{tabular}{|c|c|c|c|}
\hline Item & Ability to & Mean & Level \\
\hline 1 & understand the general information search process. & 3.2 & High \\
\hline 2 & identify the appropriate information retrieval systems or tools. & 3.1 & High \\
\hline 3 & $\begin{array}{l}\text { identify and use the source of help given in an information retrieval system } \\
\text { or tools. }\end{array}$ & 3.2 & High \\
\hline 4 & consider the cost and benefit of accessing an information source. & 3.1 & High \\
\hline 5 & $\begin{array}{l}\text { construct and use effective search strategies and techniques for the } \\
\text { information retrieval system or tool selected. }\end{array}$ & 3.3 & $\begin{array}{l}\text { Very } \\
\text { High }\end{array}$ \\
\hline 6 & identify the purpose and target audience of an information source. & 3.2 & High \\
\hline 7 & identify the different formats of information sources. & 3.0 & High \\
\hline 8 & $\begin{array}{l}\text { identify and differentiate the primary, secondary and tertiary sources of } \\
\text { information. }\end{array}$ & 3.0 & High \\
\hline 9 & understand and identify formal and informal sources of information. & 3.1 & High \\
\hline 10 & $\begin{array}{l}\text { understand and identify the major disciplines and sub-disciplines of } \\
\text { knowledge. }\end{array}$ & 3.1 & High \\
\hline 11 & revise or modify the information need. & 3.0 & High \\
\hline 12 & identify the key concepts that describes the information need & 3.2 & High \\
\hline
\end{tabular}

Table 5 shows the mean score for each item at a high level with the overall achievement of the mean level greater than 3.0 except for item 13 which only reaches mean at level 2.8 only. There were two items of questionnaire which reached a very high level of item 16 and item 20 which showed that the students had ability to extract relevant information in a very high level in terms of taking notes in a systematic way and recording relevant information.

Table 5 - Mean Score for Every Extracting Relevant Information Item

\begin{tabular}{lllc}
\hline Item & Ability to & Mean & Level \\
\hline 13 & skim and scan information resources to find relevant information or ideas. & 2.8 & High \\
\hline 14 & $\begin{array}{l}\text { understand what is being read, viewed or listened to and the ability to relate } \\
\text { this to existing knowledge. }\end{array}$ & 3.0 & High \\
\hline 15 & $\begin{array}{l}\text { select the appropriate information and reject information in the context of } \\
\text { the purpose identified for using a particular information resource. }\end{array}$ & 3.15 & High \\
\hline 16 & take notes in a systematic way which relates to understanding and purpose. & $\mathbf{3 . 4 5}$ & $\begin{array}{l}\text { Very } \\
\text { High }\end{array}$ \\
\hline 17 & $\begin{array}{l}\text { bring together related ideas, facts and information about a topic and relating } \\
\text { this to existing knowledge. }\end{array}$ & 3.09 & High \\
\hline 18 & determine presentation format and to develop communication skills. & 3.22 & High \\
\hline 19 & choose and extract relevant information. & 3.06 & High \\
\hline 20 & $\begin{array}{l}\text { record relevant information through note making or making a visual } \\
\text { organizer such as a chart, graph, or outline, etc. }\end{array}$ & $\mathbf{3 . 3}$ & $\begin{array}{l}\text { Very } \\
\text { High }\end{array}$ \\
\hline 21 & determine which sources are too easy, too hard, or just right. & 3.1 & High \\
\hline
\end{tabular}

Table 6 shows the mean score for each item at a high level with the overall achievement of the mean level greater than 3.0 except for item 31 which only reaches mean at 2.9 level only. There were no questionnaires that reached a very high mean of mean exceeding 3.25.

Table 6 - Mean Score for Each Synthesizing the Information Item

\begin{tabular}{llll}
\hline Item & Ability to & Mean & Level \\
\hline 22 & $\begin{array}{l}\text { take bits and pieces of information and creating a new and coherent thought from } \\
\text { them. }\end{array}$ & 3.06 & High \\
\hline 23 & organize information from multiple sources. & 3.02 & High \\
\hline 24 & summarize the main ideas from information gathered. & 3.1 & High \\
\hline 25 & synthesize the main ideas to construct new concepts. & 3.1 & High \\
\hline 26 & present the information in a creative way. & 3.2 & High \\
\hline 27 & $\begin{array}{l}\text { organize the content in a way the supports the purpose and format of information } \\
\text { product or performance. }\end{array}$ & 2.56 & High \\
\hline 28 & $\begin{array}{l}\text { integrate and manipulate information such as text (print/digital), images and data, } \\
\text { as needed, for the development of the new information product or performance. }\end{array}$ & 3.0 & High \\
\hline
\end{tabular}




\begin{tabular}{llcc}
\hline 29 & revise the development process of the information product or performance. & 3.1 & High \\
\hline 30 & use information from several sources to create new ideas based on analysis. & 3.2 & High \\
\hline 31 & infer and summarise into a complete and original understanding of the text. & $\mathbf{2 . 9}$ & High \\
\hline 32 & $\begin{array}{l}\text { infer relationships among sources. } \\
\text { collect and discard from among the information generated by the information } \\
\text { strategy process. }\end{array}$ & 3.0 & High \\
\hline 34 & $\begin{array}{l}\text { generate through the information strategy process enables communicators to make } \\
\text { idea. }\end{array}$ & 3.1 & High \\
\hline
\end{tabular}

Table 7 shows the mean score for most items at a high level with overall reaching the mean level of 3.0 except for item 40 and 43 which only reaches mean at level 2.9 only. There is a questionnaire that achieves a very high level of mean with a mean value of more than 3.25 which is a 36 item that shows that teachers have Evaluating skills in a very high level in terms of "reflect on the processes involved in assignment-related work".

Table 7 - Mean Score per Evaluating to Communicate the Information Items

\begin{tabular}{|l|l|l|l|}
\hline Item & Ability to & Mean & Level \\
\hline 35 & $\begin{array}{l}\text { identify areas of improvement in the effective use of information resources in the } \\
\text { future. }\end{array}$ & 3.1 & High \\
\hline 36 & $\begin{array}{l}\text { reflect on the processes involved in assignment-related work } \\
\text { begin thinking about how the project went and consider } \\
\text { possibilities for the future. }\end{array}$ & $\mathbf{3 . 3}$ & $\begin{array}{l}\text { Very } \\
\text { High }\end{array}$ \\
\hline 38 & evaluate the process and the project/results. & 3.1 & High \\
\hline 39 & review the research process and compare and evaluate the information and data. & 3.0 & High \\
\hline 40 & judge the product effectiveness and judge the process efficiency. & $\mathbf{2 . 9}$ & Low \\
\hline 41 & $\begin{array}{l}\text { use the feedback and assessment for the next } \\
\text { learning activity / task. }\end{array}$ & 3.1 & High \\
\hline 42 & determine in what other subjects the skills can be used. & 3.0 & High \\
\hline 43 & $\begin{array}{l}\text { apply initial criteria's such as authority, accuracy, validity, reliability, timeliness } \\
\text { and point of view or bias for evaluating information source. }\end{array}$ & $\mathbf{2 . 9}$ & Low \\
\hline 44 & evaluate both print and electronic information sources. & 3.1 & High \\
\hline
\end{tabular}

\section{Correlation of Components of Information Skills Used in the Report Writing}

Analyze whether there is a significant the correlation of locating information source with extracting relevant information; synthesizing the information and evaluating to communicate the information and the relationship between locating information source with extracting relevant information, synthesizing the information and evaluating to communicate the information among teachers.

Table 8 shows that there is a significant relationship between locating information source and extracting relevant information $(r=.975, p=.000)$, synthesizing the information $(r=.976, p=.000)$ and evaluating to communicate the information $(\mathrm{r}=.98, \mathrm{p}=.000)$.

The findings showed that all null hypotheses were successfully rejected which proved that there was a significant relationship between all the variables studied.

Table 8 - Correlation analysis between LOC with EXTRACT, SYNTHESIZE AND EVALUATE

\begin{tabular}{|l|l|l|l|}
\hline Hypothesis & Value $\mathrm{r}$ & Value $\mathrm{p}$ & Decision \\
\hline $\begin{array}{l}\text { There was no significant relationship between locating information } \\
\text { source and extracting relevant information among teachers. }\end{array}$ & .98 & .000 & Rejected \\
\hline $\begin{array}{l}\text { There was no significant relationship between locating information } \\
\text { source and synthesizing the information among teachers. }\end{array}$ & .98 & .000 & Rejected \\
\hline $\begin{array}{l}\text { There was no significant relationship between locating information } \\
\text { source and evaluating to communicate the information among. teachers }\end{array}$ & .98 & .000 & Rejected \\
\hline
\end{tabular}

Indicator:

LOC- locating information source

EXTRACT- extracting relevant information 
SYNTHESIZE - synthesizing the information

EVALUATE - evaluating to communicate the information

\section{Pre-Test and Post-Test}

The results of the post-test were more encouraging than the pre-test. The best result in the pre-test was in the 'summary' and the best score for the post-test was in 'Direct Quotations'. A comparison of the results of the pre-test and the post-test reflected the overall performance of participants in Information skills in the English Language Proficiency Course. It also proved to be a yardstick for the researcher where pedagogical skills were concerned.

\section{Report Writing}

The results of the report writings were very encouraging. 20 out of 24 participants secured distinctions, with 2 securing credits and 2 just making the grade. As most of the scores obtained for the whole report writing were good, it indicated that the course on information skills had enabled them to write effectively in their report writings. The high scores too, were a testimony of the participants' effective and accurate application of information skills in their report writings.

\section{Journals}

In the journals, the participants reflected that the input received on information skills, followed by practical sessions to practise skills to dove-tail into search for information regarding their report writing topic had helped them tremendously at the initial stages. They did not encounter any problems when attending the training activity as their course mates as well as the trainer were very supportive. In their journal, they also expressed the fact that the course component 'Information Skills' had helped them tremendously in library research and had enabled them to retrieve information on a topic easily. They were able to glean appropriate information from books, newspaper, thesaurus, encyclopedia, self-access materials and the Internet for information to write their report. They became competent to assess, analyze, evaluate and communicate appropriate information from variety of resources for their report writing. In their last journal, they also expressed the fact that the interaction and training activity had helped them tremendously in most notably in situations requiring decision making, problem solving, or the acquisition of knowledge and had enabled them to retrieve information on a topic easily. They were able to assess, analyze, evaluate and communicate appropriate information from variety of resources for their report writing.

\section{Introspection to Find Out the Attitudes towards Report Writing}

An analysis of the data in the introspection revealed that all the course participants were unanimous in maintaining that they were not adequately prepared for report writing. An overwhelming $66 \%$ of the course participants were unclear about the objectives of report writing. This ignorance was reflected in their attitude towards report writing. 83.3\% of the course participants admitted that they were not serious about report writing. Findings suggest that nobody enjoyed report writing and $75 \%$ of them believed that report writing was a burden to them. $75 \%$ of the course participants also felt that writing report was a waste of time and were sure that they would not continue to write report after their CPD English language Proficiency course. Only a handful, $12.5 \%$ of the course participants were aware of the general benefits of writing report. All of them believed that feedback from trainer regarding their writing was important. However, only $33 \%$ of the course participants could see the relationship between report writing and there in their teaching career.

An analysis of the data in the introspection was consistent with the findings gleaned from informal interviews. Course participants who claimed that they could see the relationship only had a vague idea of it. Examples of such vague ideas were:

- "Writing report is the in-thing now; every professional should write...."

- "In teaching, writing report will make the teachers remember things better"

- "When teachers write, they can find out more about their students' weaknesses"

Generally, the findings indicate that much needs to be done with regard to the respondents' understanding and attitudes towards report writing.

Finally, the findings also suggested that in the initial stages, the course participants had a very negative attitude towards report writing. This could be due to their ignorance of its benefits and their own inability to apply the information skills. However, the findings also showed that all these could be changed when the proper input and practice were given. The generally positive shift in the course participants' attitude was a sign that the lecturer had been moving in the right direction. As findings revealed, a small percentage of the course participants were 'die-hards' who refused to change but the reasons given by them were interestingly valid. It can be concluded that given a time, concerted effort, it is possible to do adaptive modification attitude of the course participants. 
The findings show that overall the skills are in the $($ Mean $=3.12, \mathrm{SD}=.52)$ locating information source, $($ Mean $=$ $3.1, \mathrm{SD}=.496)$ extracting relevant information, (Mean $=3.04, \mathrm{SD}=.53)$ synthesizing the information and evaluating to communicate the information (Mean $=3.07, \mathrm{SD}=.52$ ). This finding shows that students can master all skills if they have been exposed and trained. Lundstrom Kacy et. Al (2015) conducted a research to determine how information synthesis skills can be taught effectively, and to discover how the level of synthesis in student writing can be effectively measured. The findings that teachers attending the CPD possessed information skill knowledge. They acquired information skills because they know it when and why they require information, where to locate it, and how to assess, utilize, and communicate it morally and legitimately. The result of this study is in line with that of Sumpter (2006) who found that LIS postgraduate students demonstrated high proficiency in information literacy knowledge. Furthermore, the result reveals that LIS postgraduate students possessed a moderate level of information literacy skills. This is because they are moderately skilled in locating and accessing information, evaluating information, and highly skilled in using information. This is as posited by Ojedokun (2007) that information literacy skills in all disciples requires an individual to be able to define problem; initiate a plan to find information; locate and access resources; use the information; synthesize information; and carry out some forms of evaluation.

The findings also show that there is a significant relationship at the very strong level between all the variables between locating information source, extracting relevant information, synthesizing the information and evaluating to communicate the information. Studies on the relationship between locating information source, extracting relevant information, synthesizing the information and evaluating to communicate the information have indeed showed a significant relationship between all variables.

\section{Conclusion}

The findings were favourable. More than fifty percent of the course participants obtained distinction for their report writings. The high scores obtained for the overall report writing were an indication of participants' total comprehension and application of the course component. The favourable post-test results manifested that the input on information skills had been used accurately and effectively. They had manifested a good mastery of information skills in terms of precision of ideas and thoughts as well as coherence and cohesion in writing. The journals gave an insight into participants' feelings and perceptions regarding the course. The interviews were an added source of information for the reports writing. In addition, the questionnaire on the information skills component yielded positive results with a majority claiming that the course was necessary for the effective writing reports. From this study, it can be concluded that given time concerted efforts and a good mastery of information skills in terms of precision of ideas and thoughts as well as coherence and cohesion in writing, it is possible to raise the level of writing competency of the course participants.

An information literate learner is able to: recognize a need for information; determine the extent of information needed; access information efficiently; critically evaluate information and its sources; classify, store, manipulate and redraft information collected or generated; incorporate selected information into their knowledge base; use information effectively to learn, create new knowledge, solve problems and make decisions; understand economic, legal, social, political and cultural issues in the use of information; access and use information ethically and legally; use information and knowledge for participative citizenship and social responsibility; and experience information literacy as part of independent learning and lifelong learning (Bundy, 2004).

\section{Acknowledgment}

The author would like to express their gratitude to Training Development Department, Institute of Teacher Education Tun Hussein Onn Kampus, Batu Pahat, Johor, Malaysia for the assistance and the information provided to ensure the success of the study.

\section{References}

[1] Borg, S (2015) Researching language teacher education in Paltridge, B and Phakiti, A (eds), The Continuum companion to research methods in applied linguistics (Second ed., pp. 541-560). London: Bloomsbury

[2] Bundy, A. (Ed.). (2004). Australian and New Zealand Information Literacy Framework: Principles, Standards and Practice (2nd ed.). Adelaide, SA: Australian and New Zealand Institute for Information Literacy

[3] Burke, Jim. "School Tools." English Companion. 2007. 27 Apr 2008

[4] Carnavale, Anthony P. and Rose, Stephen J. 2015. "The Economy Goes to College: The Hidden Promise of Higher Education in the Post-Industrial Service Economy.” Washington, D.C.: Georgetown University Center on Education and the Workforce

[5] Chomsky, N. 2000. Minimalist inquiries: The framework. Step by step ed.by Martin, Roger, David Michaels \& Juan Uriagereka

[6] Chow, Barbara. 2010. "The Quest for 'Deeper Learning'," October 06, Education Week

[7] Common Core State Standards Initiative 2010, 4. https://www.aeseducation.com/blog/what-are-iste-standards 
[8] Common Core State Standards for English language arts and literacy in history/social studies, science, and technical subjects. Washington, DC: Authors. Retrieved August 3, 2012, from https://www.corestandards.org/assets/CCSSI_ELA\%20 Standards.pdf

[9] Day, C (1999) Developing teachers: The challenges of lifelong learning. London: Falmer Press

[10] Earley, P and Porritt, V (2014) Evaluating the impact of professional development: The need for a student-focused approach. Professional Development in Education 40/1: 112-129

[11] Eisenberg, M. B. \& Berkowitz, R. E. (2000). Teaching information \& technology skills: The Big6 in secondary schools. Worthington, Ohio: Linworth Publishing

[12] Eisenberg, Michael B. \& Berkowitz, Robert E. (2001). The Big 6 Information Process Model Retrieved and available at http://www.big6.com/

[13] Eisenberg, M. B. \& Johnson, D. (2002). Computer Skills for Information Problem-Solving: Learning and Teaching Technology in Context. ERIC Digest EDO-IR-96-04. Syracuse, NY: ERIC Clearinghouse on Information and Technology

[14] Frerichs, Mike. "Big6 Problem-Solving with Multimedia Web Design Teams." [Weblog February 26, 2008$] 2008$. Big6: Information and Technology Skills for Student Achievement. 27 Apr 2008

[15] Gordon, J. (2006) Memo to students: Writing skills matter, BusinessWeek, 26 April. Available at http://www. businessweek.com/bschools/content/apr2006/bs20060426_682947.htmhttps://www.thestar.com.my/news/educatio $\mathrm{n} / 2019 / 06 / 09 /$ boosting-english-

[16] Kovalik, C. L., Jensen, M. L., Schloman \& Tipton, M. (2010). Information literacy collaboration, and teacher education. Communication and Information Literacy, 4,145-169

[17] Lundstrom, Kacy et.al. (2015) An Information Literacy Snapshot: Authentic Assessment Across the Curriculum. College \& Research Libraries.76 (2) 170-187

[18] Martinez, Monica (November 13, 2014) "6 Rules to Break for Better, Deeper Learning Outcomes" Edutopia. George Lucas Education Foundation

[19] National Education Blueprint 2013 - 2025: Preschool to Post-Secondary Education. (2013). Putrajaya: Ministry of Education Malaysia

[20] National School Library Standards Crosswalk | standards.aasl.org | Copyright (C) 2018, American Association of School Librarians, a division of the American Library Association. All Rights Reserved

[21] Nurul Farehah and Mohd Sallehhudin Abd Aziz (2017) Unpublished doctoral Thesis

[22] Ojedokun, A. A. (2007). Information literacy for tertiary education students in Africa. Ibadan: Third world information services limited

[23] Pajares, F. (2003). Self-efficacy beliefs, motivation, and achievement in writing: A review of the literature. Reading and Writing Quarterly, 19, 139-158.10.1080/10573560308222

[24] Pellegrino, James, Hilton, Margaret, Herman, Joan, et.al.2012. Education for Life and Work: Developing Transferrable Knowledge and Skills in the 21st Century. Washington, D.C.: National Research Council

[25] Sara Wolf (2003) The Big Six Information Skills as a Metacognitive Scaffold: A Case Study. School Library Media Research, Vol 6, 2003. ISSN: 1523-4320

[26] Saville, N (2005) An interview with John Trim at 80, Language Assessment Quarterly 2 (4), 263-288

[27] SECRETARÍA DE EDUCACIÓN PÚBLICA (SEP,2002). Programa Nacional de Educación 2001-2006. Por una educación de buena calidad para todos: un enfoque educativo para el siglo XXI. 83-219. Retrieved November 24, 2007, from: http://www.sep.gob.mx/work/ appsite/ programa/plan.zip

[28] Separuh guru BI tak mahir bahasa Inggeris, kata akademik ...https://www.freemalaysiatoday.com

[29] So, W., CHENG, M. and TSANG C. (1996). Un Impacto en la Práctica de la Enseñanza: Percepciones de las competencias del maestro entre estudiantesmaestros. Universidad de Hong Kong

[30] Story-Huffman, Ru. "Location and Access: Threading the Needle (Higher Education)." [Weblog June 10, 2006] 2008. Big6. 28 Apr 2008

[31] Sumpter, J. (2006). A baseline assessment of information literacy competencies of students in the school of public health at the University of North Carolina at Chapel Hill. (Master's thesis, University of North Carolina)

[32] The new Big6.org team talk with Mike Eisenberg about the Big 6 information problem solving model and how the Big 6 is moving into the future. (January 21, 2019 on Facebook Live). https://www.youtube.com/watch?time_continue=6\&v=tlQs58BO5ZA\&feature=emb_logo

[33] William and Flora Hewlett Foundation. 2013. "What is Deeper Learning?"

[34] Wolinsky, Art. Internet Power Research Using The Big6 Approach. Berkeley Heights, NJ: Enslow Publishers, Inc., 2002 